${ }^{1}$ Dr. Öğr. Üyesi, Alanya Alaaddin Keykubat Üniversitesi, Antalya, Türkiye, davut.karaman@alanya.edu.tr

ORCID: 0000-0001-9097-3460

\section{The effect of relationship marketing on customer satisfaction in insurance agencies}

\author{
Sigorta acentelerinde ilişkisel pazarlamanın müşteri memnuniyetine \\ etkisi
}

\author{
Davut Karaman ${ }^{1}$
}

\begin{abstract}
The research aims to determine the effect of relational marketing on customer satisfaction in insurance agencies. The research is a quantitative study, and the survey method was used. The applied questionnaire was composed of scales whose reliability and validity were proven in the literature. In this context, the data for the research was obtained by questionnaire from consumers in Antalya between September-November 2019 and using home or car insurance services in insurance agencies. The data obtained from the questionnaires conducted with 461 participants were evaluated in the SPSS 25.0 package program, and regression analyses were carried out in line with the research purpose. First, the scale was subjected to factor analysis, and Cronbach Alpha values were calculated. According to the results, the scale is reliable and valid. Then, the means of the scale items were calculated. According to the results of the mean analysis, it can be said that the perceptions of the participants regarding the competence of the insurance agency they receive service from are higher than the other dimensions. According to the results of the regression analysis, trust, communication commitment, and competence, which are four dimensions of relational marketing in insurance agencies, have a positive effect on customer satisfaction.
\end{abstract}

Keywords: Relationship Marketing, Satisfaction, Insurance Agents, Direct Selling

Jel Codes: M31, L10

\section{Öz}

Araştırmanın amacı, sigorta acentelerinde ilişkisel pazarlamanın müşteri memnuniyeti üzerindeki etkisini belirlemektir. Araştırma nicel bir çalışama olup anket yöntemi kullanılmıştır. Uygulanan anket literatürde güvenirliği ve geçerliliği kanitlanmış ölçeklerden oluşturulmuştur. Bu kapsamda araştırmanın verileri, Eylül-Kasım 2019 tarihleri arasında Antalya'da ikamet eden ve sigorta acentelerinde konut veya araba sigortası hizmeti kullanan tüketicilerden anket yoluyla elde edilmiştir. 461 katılımcı ile gerçekleştirilen anketlerden elde edilen veriler spss 25.0 paket programında değerlendirilmiş olup, araştırma amacı doğrultusunda regresyon analizleri yapılmıştır. Ölçek faktör analizine tutulmuş ve Croanbach Alpha değerleri hesaplanmıştır. Sonuçlara göre ölçek güvenilir ve geçerlidir. Ardından ölçek ifadelerinin ortalamaları hesaplanmıştır. Ortalama analizi sonucuna göre katılımcıların hizmet aldıkları sigorta acentesinin yetkinliğine ilişkin algılarının diğer boyutlara kıyasla daha yüksek olduğu söylenebilir. Regresyon analizi sonuçlarına göre, sigorta acentelerinde ilişkisel pazarlamanın dört boyutu olan güven, iletişim, bağlılık ve yetkinlik müşteri memnuniyeti üzerinde olumlu bir etkiye sahiptir.

Anahtar Kelimeler: İlişkisel Pazarlama, Memnuniyet, Sigorta Acenteleri, Doğrudan Satış

JEL Kodlar1: M31, L10
Citation: Karaman, D., The effect of relationship marketing on customer satisfaction in insurance agencies, bmij (2021) 9 (4): 1300-1314, doi: https://doi.org/10.15295/bmij.v9i4.1890 


\section{Introduction}

Marketing is a social and managerial process where individuals obtain what they want and need by exchanging with suppliers (Kotler and Armstrong, 2010). Customers now have a variety of alternatives to choose from, so they can easily switch to competitors committed to offering higher quality products at lower prices (Bhardwaj, 2007). Therefore, marketing has shifted from transactional to relational marketing (Al-Hamed and Amin, 2014:49). In other words, short-term marketing practices have left their place to a long-term relationship-based marketing practice (Jibreal, 2016:7). This marketing practice, which focuses on establishing relationships with customers, maintaining and developing established relationships based on trust, is expressed as relational marketing (Kakeeto, 2011:13). With relational marketing, businesses aim to retain customers and gain profit by establishing long-term relationships with them (Kaymak, 2016: 18; Tuzunkan, 2017: 11432).

While the first aim of relational marketing is to bring new customers to the business, the second aim is to retain existing customers (Berry, 1995). Service businesses have always been relationship-oriented. The nature of service businesses is relational (Grönroos, 2017:219; Hollesen and Opresnik, 2019:104). Therefore, relational marketing should be applied to gain profits by providing customer satisfaction, creating customer loyalty and retaining existing customers, especially in service businesses (Kıliç, 2018:264). Insurance agency, one of the sectors that provide services, is one of the sectors where relational marketing is applied. Insurance is a contract that aims to compensate the damage of the insured who was damaged in terms of property, building, and life due to an accident, disaster, fire, and death (Aktuglu, 1990:14). The commitment is marketed to the customer with the insurance service by the insurance agency (Karabulut, 1998:2). Therefore, it can be said that relational marketing dimensions, especially commitment and trust, can significantly impact insurance agents.

Satisfied customers have become an essential factor in improving the economic performance of businesses in the long run. For this reason, relationship marketing is seen as a necessary tool through which customer satisfaction can be secured. It is known that customer satisfaction has a positive effect on customer loyalty. The more satisfied a customer who is in contact with the business is, the higher his commitment to the brand will be. Therefore, every satisfied customer will bring new customers to the company. On the other hand, relationship marketing activities play an essential role in the healthy realization of this process. The importance of relational marketing has been recognized and proposed as a strategy to overcome service abstraction (Berry, 1983). However, a relationship marketing orientation has received little attention in insurance agencies that provide insurance services (Shetty and Basri, 2017). In this context, Yurdakul and Dalkılıç (2006) conducted studies on the effect of relational marketing on customer loyalty in insurance agencies and Taşkın and Bengül (2013) on the impact of relational marketing on customer loyalty in the insurance sector. However, in insurance agencies that market services such as insurance, it is essential to establish long-term relationships with customers, ensure customer satisfaction, and turn customers into loyal customers. The significant gap in the existing literature that will be addressed in this study is to examine the relationship between marketing and customer satisfaction in insurance agencies. Therefore, the study aims to determine the effect of relational marketing on customer satisfaction in insurance agencies.

\section{Conceptual framework}

\section{Relational marketing}

Relational marketing emerged as an alternative to traditional marketing in the 1980s (Rooney et al., 2020: 3). Relational marketing was first used by Berry in 1983 (Kaya and Özdemir, 2014:157; Özgen ve Şimşek, 2015:1270). According to Berry (1995), relational marketing is the group of strategies applied to strengthen and protect customer relationships in service businesses. Grönroos (1996:5) defines relational marketing as establishing long-term relationships between the customer and the seller to achieve the goals. The concept of relational marketing has been described by researchers in different contexts and based on various industries. It is generally defined in the context of customer acquisition, retention, and the resulting profitability (Menconi, 1999). It is defined as marketing activities that aim to discover new values, identify these found values with the business, and provide various benefits within the scope of lifetime value by presenting them to customers (Yeğin, 2019:24).

Yaprak (2018:3) defined relationship marketing as a marketing approach that seeks to establish, develop and maintain customer-centred relationships. Relational marketing is a relationship practice made willingly about what customers expect from businesses and what the industry should know about customers (Odabaş1, 2000). Relational marketing is the organizational culture that places customer and employee relations at the centre of the business operation (Sin et al., 2002:656). Gülmez and Kitapç1 (2003:82) defined relational marketing as establishing relationships with customers and maintaining 
relationships. Whyatt and Koschek (2003) stated that relational marketing successfully created loyal customers and reduced acquiring potential customers. According to Palmatier et al. (2008), relational marketing is the process of defining, developing, maintaining, and terminating relational exchanges to increase performance. Altunoğlu et al. (2017:188) described relational marketing as an effort to establish and maintain long-term relationships to benefit businesses and customers.

As can be understood from the relational marketing definitions, relational marketing is based on longterm relationships between the business and the customer (Güt, 2019:6; Hoşgör, 2019:24). In order to establish long-term relationships, trust must be provided between companies and customers (Blois, 1996:161). Therefore, relational marketing aims to provide customer satisfaction and loyalty by establishing long-term relationships (Eser et al., 2011). Nakip and Özçiftçi (2015:2) stated that relational marketing in service businesses is mainly applied to achieve customer satisfaction and customer loyalty by creating an atmosphere of trust. Other purposes of relational marketing are as follows (Samsa and Gelibolu, 2015:287; Kaymak, 2016:28; Yürük and Kayapınar, 2016:100);

- To retain customers,

- To gain new customers,

- To monitor the developments in the sector,

- To reduce the transaction cost,

- To increase efficiency,

- To be able to anticipate market changes,

- To provide customer satisfaction,

- To increase the quality of service.

In the relational marketing literature, relational marketing has been dimensioned in various ways. Generally, these dimensions are trusted (Hawes et al., 2004; Moorman et al., 1993), competence (Chan, 2004; Day, 1994), commitment (Mowday et al., 1979; Ndubisi, 2004), communication (Sin et al., 2002; Ventura and Küçük, 2017), conflict management (Chan, 2004; Dwyer et al., 1987), empathy (Ndubisi, 2004), benevolence (Buttle, 1996), equality (Gundlach and Murphy, 1993), and sharing secrets (Crosby et al., 1990). When the relational marketing literature is examined, the framework of the objectives, dimensions, tools and problems of relational marketing is given in Figure 1.

As one of the most critical dimensions of relational marketing, the trust dimension is mentioned in most studies (Doney and Cannon, 2019:48; Erbilgin, 2018:20; Jibreal, 2016:9; Schurr and Ozanne, 2019:950; Hawes et al., 2014). Trust underlies relational marketing (Berry, 1995:243; Camgöz, 2017:22). According to Moorman et al. (1993), the dimension of trust in relational marketing is defined as the "common desire to trust" between the buyer and the service provider for shopping. In other words, trust in relational marketing is regarding fulfilling the commitments given to each other between buyer and seller (Hawes et al., 2004). The concept of trust revolves around the business and the salesperson (Panda, 2013). Morgan and Hunt (1994) also point out that the development of trust is an essential criterion in improving the buyer-seller relationship quality in financial services. The reason is that the trust environment generated creates profitable long-term relationships for buyers and sellers (Switala, 2013:98). Therefore, with the trust dimension of relational marketing, businesses can make their customers loyal to the industry by providing customer satisfaction (Ergün and Büyüker-İşler, 2019:12). Similarly, Palmatier et al. (2006) stated that trust enhances the relationship quality between buyer and seller by increasing sales efficiency and customer satisfaction. In order to determine the effect of the trust dimension of relational marketing on customer satisfaction in insurance agencies, the following hypotheses have been developed in the study;

$\mathrm{H}_{1}$ : The trust dimension of relational marketing positively affects the satisfaction of insurance agents' customers.

Like trust, commitment is one of the critical dimensions to understand the power of relational marketing, and it is the most widely used dimension in relational marketing studies (Anderson et al., 2019). Commitment is a valuable dimension to estimate the probability of customer loyalty and the frequency of future purchases (Dwyer et al., 1987; Gundlach et al., 1995). Moorman et al. (1992) defined the commitment in relational marketing as the desire to continue the relationship established between the parties. In other words, the commitment is that customers are willing to make more effort on behalf of the business, believing that they will gain more benefits from established relationships (Mowday et 
al., 1979). Russbult and Buunk (1993) stated that commitment is required to show a stable long-term relationship between business and customers. As can be understood from these definitions, with the dimension of commitment, customer goals and objectives of the company are more integrated, and mutual harmony is achieved (Hall et al., 1970). In order to determine the effect of the commitment dimension of relational marketing on customer satisfaction in insurance agencies, the following hypotheses have been developed in the study;

$\mathbf{H}_{2}$ : The commitment dimension of relational marketing has a positive effect on the satisfaction of customers of insurance agents.

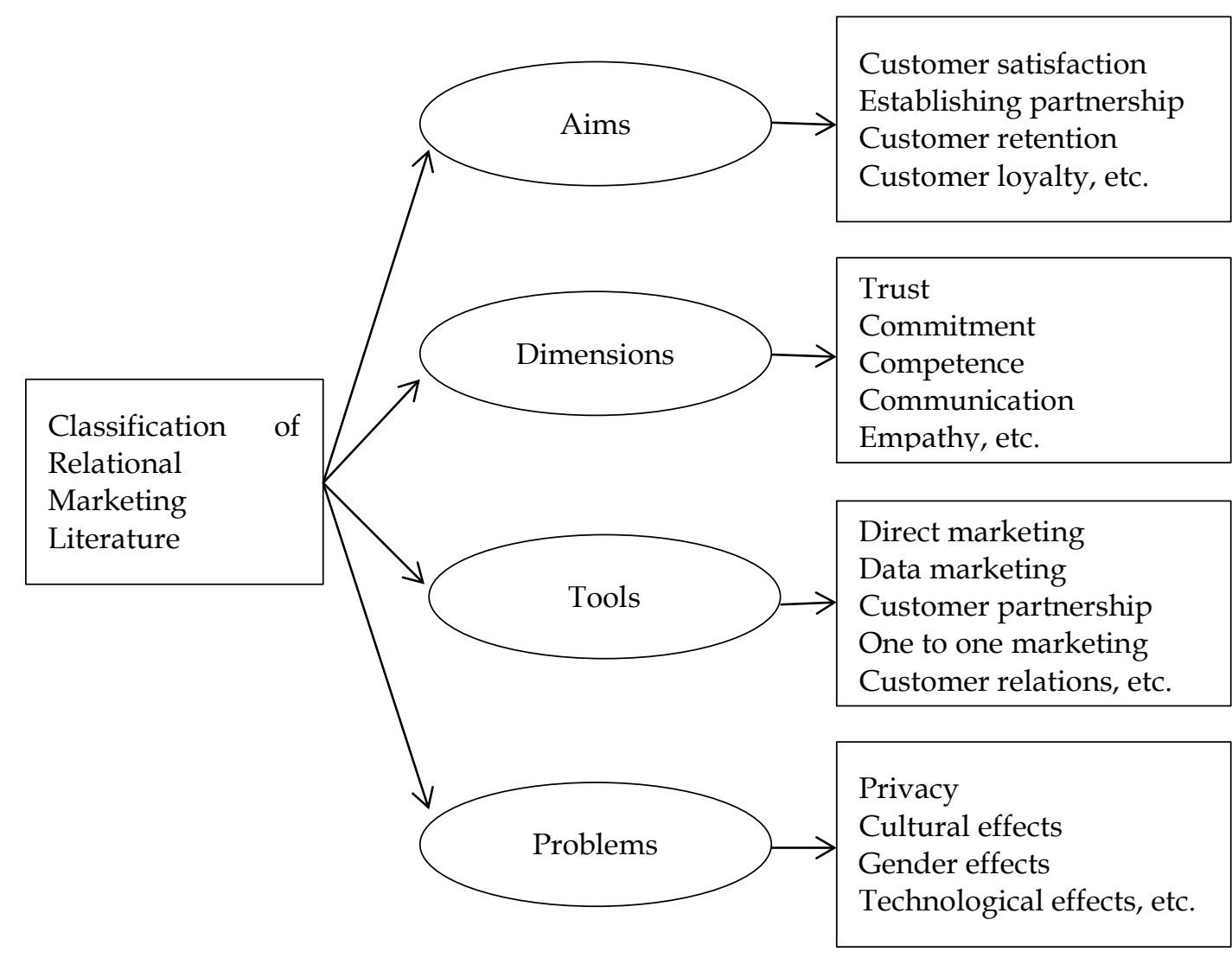

Figure 1: Classification of Relational Marketing Literature (Lindgreen, 2001)

Communication is related to providing timely and reliable information. Communication is the exchange of information between seller and customer. Such flow of information should be provided in a timely and dependable manner (Selnes, 1998; Y1lmaz, 2015:27). There is a view of communication as an interactive dialogue between customers and business during the pre-sales, sales, consumption and postconsumption steps (Anderson and Narus, 1990). With the communication in which timely and correct information flow is provided, a climate of trust is created between the customer and the company. As a result, customer satisfaction is achieved (Sin et al., 2002). In order to determine the effect of the communication dimension of relational marketing on customer satisfaction in insurance agencies, the following hypotheses have been developed in the study;

$\mathbf{H}_{3}$ : The communication dimension of relational marketing positively affects the satisfaction of insurance agents' customers.

Competence, another dimension of relational marketing, is defined as the buyer's perception regarding the supplier's competence, such as technological, commercial, and personnel issues (Anderson and Weitz, 1989). As one of the essential dimensions of relational marketing, competence is supported because people tend to value and develop relationships with competent individuals. Such competence can be achieved through intellectual, commercial, technical, and social skills (Ndubisi, 2009). Competence is operationalized in four ways: (1) the supplier's knowledge of the market for the buyer, (2) the ability to give good advice about the operating business, (3) the ability to help the buyer plan purchases, and (4) the ability to provide effective sales promotion policies (Winter, 2003). In order to determine the effect of the competence dimension of relational marketing on customer satisfaction in insurance agencies, the following hypotheses have been developed in the study; 
$\mathrm{H}_{4}$ : The competence dimension of relational marketing has a positive effect on the satisfaction of customers of insurance agents.

\section{Customer satisfaction and relational marketing}

Although the topic of satisfaction has been studied extensively in marketing (Moliner et al., 2013:198; Pappu and Quester, 2006), it is seen that there is no generally accepted definition of satisfaction (Tsiotsou, 2006). Overall satisfaction is the satisfaction of the post-purchase experience compared to the expectation before purchasing a product. In other words, it is the difference between expected performance and actual performance (İlter, 2005:25). Yi (1990) defined satisfaction as the customer's attitudes after purchasing behaviour, while Oliver (1997) defined satisfaction as the level of satisfaction resulting from the consumer's consumption or experience of the product. Based on the definition of satisfaction, satisfaction arises from the consumers' evaluation of the product after the purchase. With assessments, the satisfaction level of the customers can be realized as high satisfaction, low satisfaction or dissatisfaction (Zboja and Voorhees, 2006).

The concept of customer satisfaction is related to meeting the customers' needs, expectations, and requests and sometimes going beyond that. Therefore, it can be said that customer satisfaction and customer expectations are intertwined. Customer satisfaction is the fulfilment or exceeding of customer expectations (Akçay and Okay, 2009:465). Customer satisfaction arises when the customer compares the price they pay after the purchase and what they get (Blanchard and Galloway, 1994). According to a similar definition, customer satisfaction is the feeling of satisfaction in the customer due to the output obtained after purchasing and experiencing the product (Oliver, 1999:34). Therefore, one of the critical goals of relational marketing is to ensure customer satisfaction (Bennet and Barkensjo, 2005).

It has been revealed in some studies (Aydın and Tavukçu, 2019:162; Putra and Putri, 2019:233; Ndubisi, 2003) that relational marketing affects consumers' satisfaction with the products and their decision to continue their relationship with the business. According to Molina et al. (2007:253), customers' feeling valuable and unique due to long-term relationships between customers and enterprises contributes positively to customer satisfaction. When customers are satisfied, the probability of leaving the connection with the company and speaking decreases (Hirchman, 1970; Richins, 1983). In addition, customer satisfaction increases the tendency of customers to buy again and recommend the business (Leverin and Liljander, 2006:232).

The long-term relationship businesses establish with customers is critical for companies to know their customers and increase their satisfaction (Kotler, 2000:267). The reason for this is that to satisfy the customers. Therefore, it is necessary to know the customers closely. At this point, relational marketing comes into play. Long-term relationships with customers increase the customer's trust in the business and positively affect customer satisfaction (Nakıboğlu, 2008:143). Therefore, one of the main goals of relational marketing is customer satisfaction, and the goal at all levels is to provide customer satisfaction (Gordon, 1998:123).

According to Grönroos (1996:7), relational marketing practices provide customer satisfaction by affecting customer behaviours. Thus, customers tend to buy again by showing loyalty to the business. According to Gerson (1997:56), customers satisfied with the long-term relationships established with the relational marketing successfully applied by the companies will feel loyalty to the business. Ndubisi and Wah (2005) stated in their study that trust, communication, commitment and competence, which are among the relational marketing dimensions, create long-term relationships between the customer and the company. As a result, customer satisfaction is achieved. Kurtuldu et al. (2008:324) stated in their study that trust, commitment, service quality, communication and problem solving, which are among the relational marketing dimensions, create customer satisfaction and turn them into loyal customers. Aydın and Tavukçu (2019) determined in their study examining relational marketing in the banking sector that trust, communication, conflict management, and communication, among the relational marketing dimensions, positively affect customer satisfaction, recommendation tendency and customer loyalty.

\section{Relationship marketing in insurance agencies}

Insurance agencies are within the scope of service marketing in their products. There is a one-to-one customer relationship in the sale of insurance products. In order to ensure customer satisfaction in insurance agencies, the service must be quality, the relations with the insurance agency must be longterm, and most importantly, there must be a climate of trust between the parties. Since the trust factor is essential in insurance agencies and one-to-one communication with customers in providing insurance services, insurance agencies should adopt a relational marketing approach (Yurdakul and Dalkılıç, 2006:262). Insurance agents should develop and implement strategies to continuously improve their 
relationships with their customers to establish long-term relationships with them. Therefore, it can be said that insurance agencies should focus on their customers' needs and customer satisfaction.

Yurdakul and Dalkılıç (2006) examined the effects of relational marketing practices on the loyalty of customers to insurance agencies with the data they obtained from insurance agencies operating in Kütahya. As a result, it has been determined that after-sales relationships, customer service provision and long-term communication among relational marketing practices affect the commitment of insurance agency customers to the business. Furthermore, Taşkın and Bengül (2013) conducted a study to determine the effect of relational marketing on customer loyalty in insurance agencies with the data they obtained from Dumlupinar University academicians. The study concluded that the value of the services offered to customers creates customer loyalty and will be satisfied and loyal to the insurance agency. Finally, Parsa and Sadeghi (2015) examined the effect of relational marketing on word-of-mouth communication in insurance agencies. According to the study results, it was determined that relational marketing directly affects word-of-mouth communication. In addition, it has been revealed that customers' sense of trust involves the satisfaction of the insurance agency by purchasing its products (Parsa and Sadeghi, 2015). Therefore, it can be said that with relational marketing practices, insurance agencies can establish long-term relationships to retain customers and provide loyalty (Yurdakul and Dalkılıç, 2006:103).

\section{Method}

Previous studies discussed in the literature section have clearly shown that different factors in different sectors impact customer satisfaction. Previous studies examined relational marketing models and structures tested in various sectors. The research model of the study is given in Figure 2. The model visually explains the variables to be examined: relationship marketing and customer satisfaction are the two main variables. Relationship marketing is the independent variable, and customer satisfaction is the dependent variable.

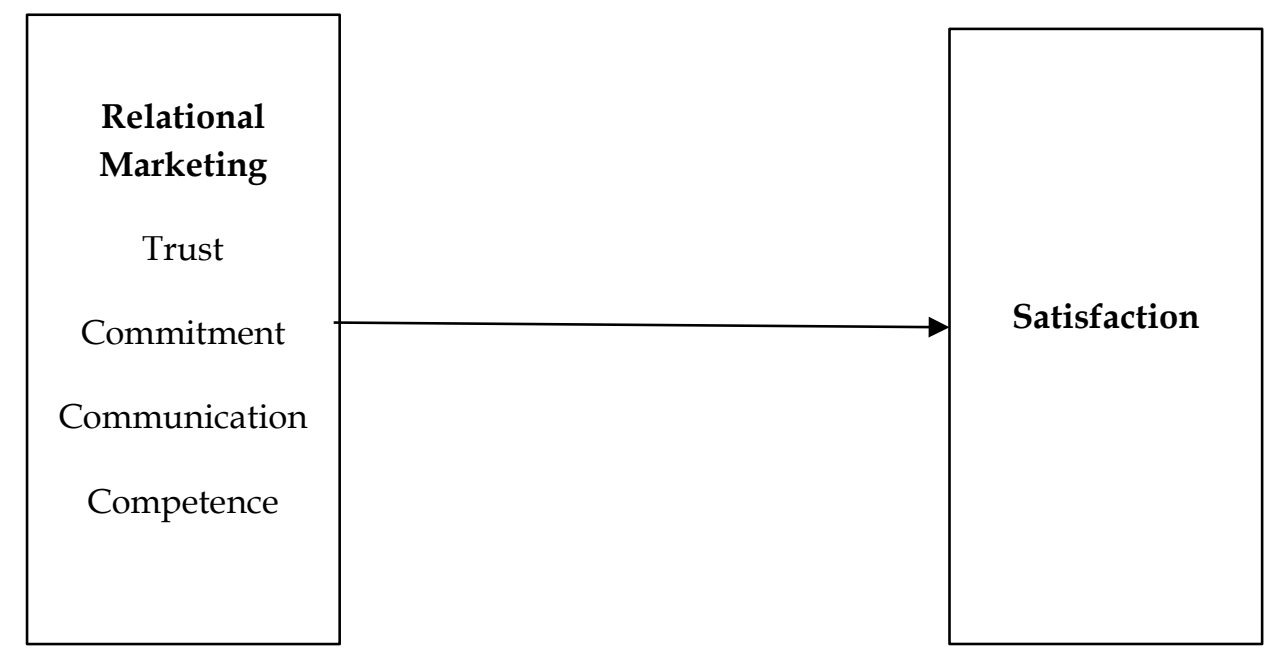

Figure 2: Study Model

The study population consists of those living in Antalya and using insurance agencies' home or car insurance services. According to TURKSTAT data of Antalya province, the number of people in 2019 is $2,511,700$. The exact number of people using home or car insurance services in insurance agencies in Antalya is unknown. Due to the bundle, the sample group having the power to represent the population with an error margin of 0,05 was accepted as (n) 384 (Yazıcıoğlu and Erdoğan, 2004). Participants in the study participated voluntarily. Due to the large population of the study, the questionnaires were applied with the convenience sampling method. The analysis of the study was carried out with a total of 416 questionnaires spread online. The data used in the study were obtained from citizens residing in Antalya province between September and November 2019. Therefore, ethics committee permission was not required. Regression analysis was applied to test the hypotheses.

The frequency analysis results regarding the demographic characteristics of the participants have summarized in Table $1.38 .7 \%$ of the participants are women and $61.3 \%$ are men. While $47.1 \%$ of the participants are married, $52.9 \%$ are single. In addition, $15.9 \%$ of the participants are 22 or younger, $28.6 \%$ are between 23 and 28, 23.3\% are between 29 and 34, $14.9 \%$ are between 35 and 40 , and $17.3 \%$ are 41 or older. Within the scope of monthly income, $20.9 \%$ of the participants do not have an income, $6.2 \%$ of them are less than the minimum wage, $13.5 \%$ are at the minimum wage level, and $59.4 \%$ of them are above the minimum wage. 
The 5 Point Likert Scale (1: Strongly Disagree, 2: Disagree, 3: Undecided, 4: Agree, 5: Strongly Agree) questionnaire was used as the data collection tool used in the study. In the first part of the questionnaire consisting of three parts, there are expressions about the demographic characteristics of the participants (gender, age, marital status and monthly income). The second part includes the "relational marketing" scale in insurance agencies, and the third part consists of the "satisfaction" scale. The scale related to relational marketing in insurance agencies was taken from the studies of Ndubisi and Wah (2005), Yurdakul and Dalkılıç (2006), Ndubisi (2009) and Aydın and Tavukçu (2019). The satisfaction scale is taken from the studies of Ndubisi (2003), Hennig-Thurau (2004) and Leverin and Liljander (2006). The scales used are those whose validity and the researchers have tested reliability.

Exploratory Factor Analysis (EFA) was conducted to validate the scales used in the study (Gürbüz and Şahin, 2015). First, kurtosis and skewness values were examined for the normal distribution of the data. The determination that the kurtosis and skewness values of most of the expressions in the scales are between (+3) and (-3) supports that the data show a normal distribution (Shao, 2002). Next, Cronbach's Alpha (CA) values of the scales were checked for reliability. According to Kalayc1 (2014), CA, importance should be above 0.60 for the reliability of the rankings. In addition, Tavşancll (2010) stated that variance rates between $40 \%$ and $60 \%$ are acceptable rates in factor analysis.

Table 1: Demographic Characteristics of the Participants

\begin{tabular}{|l|c|c|l|c|c|}
\hline \multicolumn{1}{|c|}{ Gender } & f & \% & Marital Status & f & \% \\
\hline Female & 161 & 38.7 & Married & 196 & 47.1 \\
\hline Male & 255 & 61.3 & Single & 220 & 52.9 \\
\hline Total & 416 & 100 & Total & 416 & 100 \\
\hline Income & $\mathbf{f}$ & $\mathbf{0}$ & Age & $\mathbf{f}$ & $\mathbf{\%}$ \\
\hline I have no income & 87 & 20.9 & $\mathbf{2 2}$ or younger & 66 & 15.9 \\
\hline Lower than minimum wage & $\mathbf{2 6}$ & 6.2 & $\mathbf{2 3 - 2 8}$ & 119 & 28.6 \\
\hline Minimum wage & 56 & 13.5 & $\mathbf{2 9 - 3 4}$ & 97 & 23.3 \\
\hline More than minimum wage & 247 & 59.4 & $\mathbf{3 5 - 4 0}$ & 62 & 14.9 \\
\hline Total & 416 & 100 & $\mathbf{4 1}$ or older & 72 & 17.3 \\
\hline & & Total & 416 & 100 \\
\hline
\end{tabular}

Statistical data about the dimensions of the relational marketing scale are summarized in Table 2. As a result of the factor analysis of the relational marketing scale, it was determined that it consists of 4 dimensions in total. The trust dimension consists of 7 statements. The Cronbach's Alpha (CA) value of the trust dimension is calculated as 0.96 , and the KMO value is 0.915 . The chi-square value of the trust dimension is calculated as 3194.890 . The total variance explanation ratio of the trust dimension is $80 \%$, and the factor load values of the expressions vary between 0.861 and 0.918 . The commitment dimension consists of 6 statements. The CA value of the commitment dimension is calculated as 0.94 , and the KMO value is 0.847 . The chi-square value of the commitment dimension is calculated as 2460.717 . The total variance explanation ratio of the commitment dimension is $77 \%$, and the factor load values of the expressions vary between 0.818 and 0.917 . The communication dimension consists of 4 statements. The CA value of the communication dimension is calculated as 0.96 , and the KMO value is 0.870 . The chisquare value of the communication dimension is calculated as 1858.828 (Kalaycı, 2014; Tavşancıl, 2010).

Table 2: Validity and Reliability Results of Relational Marketing Scale Dimensions

\begin{tabular}{|c|c|c|c|c|}
\hline & Trust & Commitment & Communication & Competence \\
\hline Number of Statements & 7 & 6 & 4 & 4 \\
\hline CA & 0.96 & 0.94 & 0.96 & 0.96 \\
\hline KMO & 0.915 & 0.847 & 0.870 & 0.856 \\
\hline p value & $\mathrm{p}<0,000$ & $\mathrm{p}<0,000$ & $\mathrm{p}<0,000$ & $\mathrm{p}<0,000$ \\
\hline Chi-square & 3194.890 & 2460.717 & 1858.828 & 2200.381 \\
\hline Variance Statement \% & 80 & 77 & 88 & 91 \\
\hline Factor Load Range & $0,861-0,918$ & $0,818-0,917$ & $0,917-0,955$ & $0,946-0,970$ \\
\hline
\end{tabular}

The total variance explanation ratio of the communication dimension is $88 \%$, and the factor load values of the statements vary between 0.917 and 0.955 . The competence dimension consists of 4 comments. The CA value of the competence dimension is calculated as 0.96 , and the $\mathrm{KMO}$ value is 0.856 . The chi-square value of the competence dimension is calculated 2200.381 shows that the data have a multivariate normal distribution. The total variance explanation ratio of the communication dimension is $91 \%$, and the factor load values of the statements vary between 0.946 and 0.970 . The results support the reliability and validity of the relational marketing scale (Kalayc1, 2014; Tavşanc1l, 2010).

The satisfaction scale consists of 7 statements. The CA value of the satisfaction scale is calculated as 0.95 , and the KMO value is 0.929 . The chi-square value of the satisfaction scale is calculated as 3279.052 . A 
single dimension was obtained as a result of the factor analysis performed. The total variance explanation ratio of the dimension is $79 \%$, and the factor load values of the statements vary between 0.815 and 0.944 . The results support the reliability and validity of the satisfaction scale (Kalayc1, 2014; Tavşancıl, 2010; Üztemur and Avc1, 2020).

\section{Findings}

Mean analysis was applied to the statements in the relational marketing scale to determine the participants' perception level. Means and standard deviations (SD) are given in Table 3 within the scope of dimensions.

When Table 3 is examined, it is seen that there are four statements with the highest perception. These four statements are respectively "employees in my insurance agency are experienced", "employees in my insurance agency communicate well with their customers", "my insurance agency is an expert in their field", and "employees in an insurance agency are reliable". Therefore, it can be said that the participants show a higher perception of the competence of the insurance agency where they receive service. The three expressions with the slightest perception are "My insurance agency rewards its regular customers (special discount, etc.)", "My insurance agency follows and uses technological innovations" and "My insurance agency uses quality equipment and materials", respectively. When Table 3 is examined within the scope of general averages, the expression with the highest perception is "employees in an insurance agency are reliable". The word with the slightest perception is "my insurance agency follows and uses technological innovations". The expression with the highest perception within the scope of the commitment dimension is "my insurance agency offers better service to its regular customers".

In contrast, the face with the slightest perception is "my insurance agency rewards its regular customers (special discount, etc.)". Within the scope of the communication dimension, the expression with the highest perception is "employees in my insurance agency communicate well with their customers", while the expression with the minor perception is "employees at my insurance agency put themselves in my shoes and listen to me". Within the scope of competence dimension, the expression with the highest perception is "employees in my insurance agency are experienced". In contrast, the expression with the least perception is "employees in my insurance agency are competent at their jobs". The competency dimension's average of the four statements is above 4.00 and has close standards.

Table 3: Perception Level of the Relational Marketing Scale

\begin{tabular}{|c|c|c|}
\hline Dimension and Statements & Mean & SD \\
\hline \multicolumn{3}{|l|}{ Trust } \\
\hline My insurance agency follows and uses technological innovations & 3.80 & 1.056 \\
\hline My insurance agency is always clean and hygienic & 3.91 & 1.000 \\
\hline My insurance agent uses quality equipment and materials & 3.87 & 1.019 \\
\hline My insurance agency has suitable physical means to support its services & 3.90 & 0.991 \\
\hline The employees of my insurance agency are honest and sincere & 4.02 & 1.045 \\
\hline Employees of my insurance agency are reliable & 4.06 & 0.973 \\
\hline I can easily hand over my vehicle/residence to those working at my insurance agency. & 3.88 & 1.093 \\
\hline \multicolumn{3}{|l|}{ Commitment } \\
\hline My insurance agency offers better service to its regular customers & 3.96 & 1.018 \\
\hline My insurance agent strives more for its regular customers & 3.92 & 1.028 \\
\hline My insurance agency rewards its regular customers (special discounts, etc.) & 3.62 & 1.153 \\
\hline My insurance agency provides some convenience to its regular customers & 3.88 & 1.032 \\
\hline The service I receive from my insurance agency is as good as I expect & 3.93 & 1.023 \\
\hline The service I get from my insurance agency is worth the money & 3.89 & 1.067 \\
\hline \multicolumn{3}{|l|}{ Communication } \\
\hline Employees at my insurance agency put themselves in my shoes and listened to me & 3.90 & 1.036 \\
\hline Employees at my insurance agency keep me informed on issues that are important to me & 3.97 & 1.021 \\
\hline In my insurance agency, the problems experienced by the customer are dealt with immediately. & 4.01 & 0.987 \\
\hline My insurance agency employees communicate well with their customers & 4.07 & 0.958 \\
\hline \multicolumn{3}{|l|}{ Competence } \\
\hline My insurance agency is an expert in its field & 4.06 & 0.993 \\
\hline My insurance agency employees are knowledgeable and talented & 4.02 & 1.020 \\
\hline Employees at my insurance agency are competent & 4.01 & 0.977 \\
\hline My insurance agency employees are experienced & 4.07 & 0.991 \\
\hline
\end{tabular}

In order to test the hypotheses of the research, four separate regression analyzes were conducted between the four dimensions of relational marketing and satisfaction. Results are given in Table 4. 
Table 4: Results Regarding the Hypotheses

\begin{tabular}{|l|c|c|c|c|}
\hline & Trust-Satisfaction & $\begin{array}{c}\text { Commitment- } \\
\text { Satisfaction }\end{array}$ & $\begin{array}{c}\text { Communication- } \\
\text { Satisfaction }\end{array}$ & $\begin{array}{c}\text { Competence- } \\
\text { Satisfaction }\end{array}$ \\
\hline Hypothesis & $\mathrm{H} 1$ & $\mathrm{H} 2$ & $\mathrm{H} 3$ & $\mathrm{H} 4$ \\
\hline $\mathbf{R}$ & 0.85 & 0.91 & 0.88 & 0.91 \\
\hline R-square & 0.73 & 0.83 & 0.78 & 0.82 \\
\hline F value & 1117.807 & 2064.445 & 1525.782 & 1884.845 \\
\hline Significance & 0.000 & 0.000 & 0.000 & 0.000 \\
\hline Beta & 0.854 & 0.913 & 0.887 & 0.905 \\
\hline t value & 33.434 & 45.436 & 39.061 & 43.415 \\
\hline Standard Error & 0.026 & 0.020 & 0.023 & 0.021 \\
\hline Acceptance / Rejection & Acceptance & Acceptance & Acceptance & Acceptance \\
\hline
\end{tabular}

It has been determined that the trust dimension of relational marketing in insurance agencies has a positive effect on customer satisfaction $(\beta=0.854, \mathrm{p}<0.01, \mathrm{R} 2=0.73)$. Therefore, Hypothesis 1 was accepted. It has been determined that the commitment dimension of relational marketing in insurance agencies has a positive effect on customer satisfaction $(\beta=0.913, p<0.01, R 2=0.83)$. Therefore, Hypothesis 2 was accepted. It has been determined that the communication dimension of relational marketing in insurance agencies has a positive effect on customer satisfaction $(\beta=0.887, \mathrm{p}<0.01, \mathrm{R} 2=0.78)$. Therefore, Hypothesis 3 was accepted. It has been determined that the competence dimension of relational marketing in insurance agencies has a positive effect on customer satisfaction $(\beta=0.905, p<0.01$, $\mathrm{R} 2=0.82$ ). Therefore, Hypothesis 4 was accepted.

\section{Conclusion, discussion and suggestions}

In order to determine the effect of relational marketing on customer satisfaction in insurance agencies, which is the aim of the study, data were obtained from citizens residing in Antalya province using a questionnaire. In order to test the validity and reliability of the scales used in the study, Exploratory Factor Analysis and Cronbach's Alpha analysis were performed. Data come from a normal distribution. $\mathrm{CA}, \mathrm{KMO}$, and total variance explanation ratio showed that the scales were valid and reliable. Regression analysis was used to test the study's hypotheses with the data obtained.

When the statements averages of the relational marketing scale are examined, it is determined that there are four statements with the highest perception. These four statements are respectively "employees in my insurance agency are experienced", "employees in my insurance agency communicate well with their customers", "my insurance agency is an expert in their field", and "employees in an insurance agency are reliable". Considering that trust is an essential factor for customer satisfaction and loyalty (Anderson and Narus, 1990; Samsa, 2015), the participant's perception of the employees in the insurance agency as reliable can help the agency create a loyal customer profile by creating a dedicated customer profile providing customer satisfaction. Since the trust factor also increases the quality of the communication between buyer and seller (Morgan and Hunt, 1994), the expression with the highest perception was determined as the statement that customers communicate well with employees.

As a result of the regression analysis performed to test the study's first hypothesis determined that the trust dimension of relational marketing in insurance agencies positively affects customer satisfaction; therefore, H1 was accepted. Studies in other sectors support this result (Hawes et al., 2004; Grönroos, 1990; Palmatier et al., 2006; Switala, 2013) that conclude and express the trust dimension of relational marketing has a positive effect on the formation of customer satisfaction. As a result of the analysis for the second hypothesis, it has been determined that the commitment dimension of relational marketing in insurance agencies positively affects customer satisfaction. This result is supported by studies (Gundlach et al., 1995; Russbult and Buunk, 1993) that indicate that the commitment dimension of relational marketing has a positive effect on the formation of customer satisfaction. As a result of the analysis for the third hypothesis, it has been determined that the communication dimension of relational marketing in insurance agencies positively affects customer satisfaction. This result is supported by studies in other sectors (Anderson and Narus, 1990; Sin et al., 2002) that conclude and express that the trust dimension of relational marketing has a positive effect on the formation of customer satisfaction. As a result of the analysis for the fourth hypothesis, it has been determined that the competence dimension of relational marketing in insurance agencies positively affects customer satisfaction. This result is supported by studies (Ndubisi, 2009) that indicate that the commitment dimension of relational marketing positively affects the formation of customer satisfaction.

When the findings are evaluated in general, it can be said that relational marketing applied in insurance agencies affects and increases customer satisfaction. For this reason, it is recommended that insurance agencies develop and implement relational marketing practices to ensure customer satisfaction and 
make their customers loyal. Furthermore, especially in trust and competence, insurance agencies should provide confidence to their customers and present their transactions with the latest technologies and expert employees.

The study was carried out using a questionnaire from citizens residing in Antalya and receiving home and residence insurance services. It is thought that the study of relational marketing in the context of other samples and other variables and in different sectors in future studies will contribute to the literature and businesses.

\section{Peer-review:}

Externally peer-reviewed

\section{Conflict of interests:}

The author(s) has (have) no conflict of interest to declare.

\section{Grant Support:}

The author(s) declared that this study has received no financial support.

\section{References}

Akçay, M. and Ş. Okay (2009). “Otomotiv Yetkili Servislerinde Diş Müşteri Memnuniyetine Etki Eden Faktörler Üzerine Bir Alan Araştırması: Denizli, Aydın, İzmir Örneği", 5. Uluslararası İleri Teknolojiler Sempozyumu, 13-15 Mayıs, Karabük.

Aktuglu, M. A. (1990), Sigorta İşletmeleri ve Muhasebesi, İzmir: Ege Üniversitesi Yayınları.

Al-Hamed, G. and S. T. Amin (2014), "Theoretical Foundations of Relationship Marketing", International Journal of Recent Technology and Engineering, Vol. 3, No. 5, 47-52.

Altunoğlu, A., A. D. Işık and R. Erbilgïn (2017), "Sosyal Sermaye ve İlişkisel Pazarlamanın Satış Performansına Etkisi: Yat İşletmeciliğine Yönelik Nitel Bir Araştırma", Dokuz Eylül Üniversitesi Denizcilik Fakültesi Dergisi, Vol. 9, No. 2, 186-211.

Anderson, E. and Weitz, B (1989), “Determinants of Continuity in Conventional Industrial Channel Dyads", Marketing Science, Vol. 8, No. 4, 310-323.

Anderson, J. C. and J. A. Narus, (1990), "A Model of Distributor Firm and Working Partnerships", Journal of Marketing, Vol. 54, No. 1, 42-58.

Aydın, S. and A. Tavukçu (2019), “İlişkisel Pazarlama Uygulamalarının Müşteri Sadakati, Müşteri Memnuniyeti ve Müş̧erilerin Tavsiye Etme Eğilimi Üzerine Etkisi: Türk Katılım Bankacılığı Sektöründe Bir Araştırma", International Congress on Business and Marketing, 13-14 Haziran 2019, Maltepe University, İstanbul.

Bennet, R., and A. Barkensjo (2005), "Realitionship Quality, Realitionship Marketing and Client Perceptions of the Levels of Service Quality of Charitable Organisations", International Journal of Service Industry Management, Vol. 16, No. 1, 81-106.

Berry, L. L. (1983), Relationship Marketing, Emerging Perspectievs on Services Marketing, Chicago: AMA.

Berry, L. L. (1995), “Relationship Marketing of Services - Growing Interest, Emerging Perspectives", Journal of the Academy of Marketing Science, Vol. 23, No. 4, 236-245.

Bhardwaj, D. (2007), "Relationship Marketing in Context to the IT Industry", The Journal of Business Perspective, Vol. 11, No. 2, 57-66. 
Blanchard, R. F. and R. L. Galloway, R. L. (1994), “Quality in Retail Banking”, International Journal of Service Industry Management, Vol. 5, No. 4, 5-23.

Blois, K. J. (1996), "Relationship Marketing in Organizational Markets - When is it Appropriate?", Journal of Marketing Management, Vol. 12, No. 1, 161-173.

Buttle, F. (1996), Relationship Marketing. F. Buttle (Eds.), Relationship Marketing: Theory and Practice, London: Paul Chapman Publishing.

Camgöz, M. (2017). İlişkisel Pazarlamanın Müşteri Sadakatine Etkisi: Fitness Merkezi Müşterileri Üzerinde Bir İnceleme, Yayımlanmamış Yüksek Lisans Tezi, İstanbul: Bahçeşehir Üniversitesi.

Chan, K. W. (2004), Examining the Antecedents of Relationship Quality, Customer Satisfaction and Customer Loyalty, Unpublished Master Thesis, Kota Kinabalu: University of Malaysia Sabah.

Crosby, L. A., K. R. Evans and D. Cowles (1990), "Relationship Quality in Services Selling: An Interpersonal Influence Perspective", Journal of Marketing, Vol. 54, No. 3, 68-81.

Day, G. S. (1994), “The Capabilities of Market-driven Organizations”, Journal of Marketing, Vol. 58, No. 4, 37-52.

Doney, P. M. and J. P. Cannon (2019), "An Examination of the Nature of Trust in Buyer-Seller Relationships", Journal of Marketing, Vo. 61, No. 2, 35-51.

Dwyer, F. R., P. H. Schurr and S. Oh (1987), "Developing Buyer-seller Relationships", Journal of Marketing, Vol. 51, No. 2, 11-27.

Erbilgin, R. (2018), Marina İşletmeciliğinde İlişkisel Pazarlama Uygulamalarının Sadakat ve Tavsiye Etme Üzerindeki Etkisi, Yayımlanmamış Yüksek Lisans Tezi, Muğla: Muğla Sıtkı Koçman Üniversitesi.

Ergün, E. and D. Büyüker İşler (2019), “İlişkisel Pazarlama Kapsamında Sosyal Müşteri İlişkileri Yönetimi ve Konaklama İşletmelerinde Bir Uygulama", Journal of International Social Research, Vol. 12, No. 62, 1-13.

Eser, Z., S. Korkmaz and S. Öztürk. (2011), Pazarlama, Kavramlar, İlkeler ve Kararlar, Ankara, Siyasal Yayınları.

Gerson, R. F. (1997), Müşteri Tatmininde Süreklilik, (çev: T. Savaşener), İstanbul: Rota Yayınları.

Gordon, I. H. (1998), Relationship Marketing: New Strategies, Techniques and Technologies to Win the Customers You Want and Keep them Forever, Ontario: John Wiley \& Sons.

Grönroos, C. (1990), "Relationship Approach to the Marketing Function in Service Contexts: The Marketing and Organizational Behavior Interface", Journal of Business Research, Vol. 20, No. 1, 312.

Grönroos, C. (1996), "Relationship Marketing: Strategic and Tactical Implications", Management Decion, Vol. 34, No. 3, 5-14.

Grönroos, C. (2017), "Relationship Marketing Readiness: Theoretical Background and Measurement Directions", Journal of Services Marketing, Vol. 31, No. 3, 218-225.

Gundlach, G. T. and P. Murphy (1993), "Ethical and Legal Foundations of Relational Marketing Exchanges", Journal of Marketing, Vol. 57, No. 4, 35-46.

Gundlach, G. T., R. S. Achrol and J. T. Mentzer (1995), “The Structure of Commitment in Exchange", Journal of Marketing, Vol. 59, No. 1, 78-93.

Gülmez, M. and Kitapçı, O. (2003), “İlişki Pazarlamasının Gelişimi ve Yakın Geleceği”, Cumhuriyet Üniversitesi İktisadi ve İdari Bilimler Dergisi, Vol. 4, No. 2, 81-89.

Gürbüz, S. and F. Şahin (2015), Sosyal Bilimlerde Araştırma Yöntemleri, Ankara: Seçkin Yayınları.

Güt, A. (2019), İhracat İlişkisel Pazarlama Oryantasyonu: Ölçek Geliştirme, Yayımlamamış Doktora Tezi, Tekirdağ: Tekirdağ Namık Kemal Üniversitesi.

Hall, D. T., B. Schneider and H. T. Nygren (1970), "Personal Factors in Organizational Identification", Administrative Science Quarterly, Vol. 15, No. 2, 176-190.

Hawes, J. M., A. K. Rich and S. M. Widmier (2004), “Assessing the Development of the Sales Profession”, Journal of Personal Selling \& Sales Management, Vol. 24, No. 1, 27-37. 
Hennig-Thurau, T. (2004), “Customer Orientation of Service Employees: Its Impact on Customer Satisfaction, Commitment, and Retention", International Journal of Service Industry Management, Vol. 15, No. 5, 460-478.

Hirchman, A. O. (1970), Exit, Voice and Loyalty: Responses to Decline in Firms, Organizations and States, Cambridge: Harvard University Press.

Hollesen, S. and M. C. Opresnik (2019), Marketing: A Relationship Perspective, US: World Scientific Publisers.

Hoşgör, H. (2019), Sağlık İşletmelerinde İlişkisel Pazarlama Stratejileri ile Hastaların Davranışsal Niyetleri Arasındaki İlişkinin Yapısal Eşitlik Modeli İle İncelenmesi, Yayımlanmamış Doktora Tezi, İstanbul: İstanbul Üniversitesi.

İlter, D. P. (2005), Bireysel Banka Müşterilerinin Memnuniyetinin Ölçülmesi ve Bir Uygulama, Yayınlanmamış Yüksek Lisans Tezi, Eskişehir: Anadolu Üniversitesi Sosyal Bilimler Enstitüsü.

Jibreal, S. (2016), İlişkisel Pazarlama Taktiklerinin İlişki Kalitesi ve Müşteri Sadakati Üzerine Etkisi: Gana Mobil Telekomünikasyon Sektörü Üzerine Bir Araştırma, Yayımlanmamış Yüksek Lisans Tezi, İstanbul: Marmara Üniversitesi.

Kakeeto, N. T. (2011), Relationship Marketing For Smes in Uganda, Unpublished Doctorate Thesis, Holland: Tilburg University.

Kalaycı, Ş. (2014), SPSS Uygulamalı Çok Değişkenli İstatistiksel Teknikler, Ankara: Asil Yayıncılık.

Karabulut, M. (1998), Sigorta Pazarlaması, İstanbul: İ.Ü. İşletme Fakültesi Yayınları.

Kaya Y. and Özdemir, S. (2014), “Muhasebe Meslek Mensuplarının Sundukları Hizmetin Müşteri Tarafından İlişkisel Pazarlama Anlayışı Doğrultusunda Değerlendirilmesine Yönelik Ampirik Bir Çalışma", İşletme Araştırmaları Dergisi, Vol. 6, No. 4, 157-171.

Kaymak, A. (2016), İlişkisel Pazarlama ile Müşteri Değeri Yaratma: Turizm Sektöründe Bir Uygulama Örneği, Yayımlanmamış Yüksek Lisans Tezi, Afyon: Afyon Kocatepe Üniversitesi.

Kılıç, K. (2018), İlişkisel Pazarlama, Y. Akçi (Eds.), Değişen Pazarlama Anlayışı Yeni Pazarlama Yaklaşımları, Ankara: Gazi Kitapevi.

Kotler, P. (2000), Pazarlama Yönetimi, (çev: N. Muallimoğlu), İstanbul: Beta Yayınları.

Kotler, P. and Armstrong, G. (2010), Principles of Marketing, London: Prentice Hall.

Kurtuldu, H. S., Z. Çilingir and S. Yıldız (2008), “İlişki Odaklı Pazarlama Bileşenlerinin Tüketici Sadakati Üzerindeki Etkisi: Bankacılık Sektöründe Bir Uygulama”, 13.Ulusal Pazarlama Kongresi, 25-29 Ekim, Nevşehir.

Leverin, A. and V. Liljander (2006), “Does Relationship Marketing Improve Customer Relationship Satisfaction and Loyalty?", International Journal of Bank Marketing, Vol. 24, No. 4, 232-251.

Lindgreen, A. (2001), “A Framework for Studying Relationship Marketing Dyads”, Qualitative Market Research, Vol. 4, No. 2, 75-87.

Menconi, P. (1999), CRM 101: Building A Great Customer Relationship Management Strategy. D. H. Renner (Eds.), Defying the Limits: Reaching New Heights in Customer Relationship Management, San Francisco: Montgomery Research.

Molina, A., D. Martin Consuegra and A. Esteban (2007), "Relational Benefits and Customer Satisfaction in Retail Banking", International Journal of Bank Marketing, Vol. 25, No. 4, 253-271.

Moliner, J. R. S., M. A. Tena and J. S. Garcia (2013), “Relationship Quality in Business to Business: A Cross-cultural Perspective From Universities”, Marketing Intelligence and Planning, Vol. 31, No. 3, 196-215.

Moorman, C., G. Zaltman and R. Deshpande (1992), “Relationships between Providers and Users of Market Research: The Dynamics of Trust within and between Organizations", Journal of Marketing Research, Vol. 29, No. 3, 314-328.

Moorman, C., R. Deshpande and G. Zaltman (1993), Relationship between Providers and Users of Market Research: The Role of Personal Trust", Cambridge: Marketing Science Institute.

Morgan, R. M. and S. D. Hunt (1994), "The Commitment-trust Theory of Relationship Marketing", Journal of Marketing, Vol. 58, No. 3, 20-38. 
Mowday, R. T., R. M. Steers and L. W. Porter (1979), “The Measurement of Organizational Commitment", Journal of Vocational Behavior, Vol. 14, No. 2, 224-247.

Nakıboğlu, M. A. B. (2008), Hizmet İşletmelerindeki İlişkisel Pazarlama Uygulamalarının Müşteri Bağlılığı Üzerindeki Etkileri, Yayınlanmamış Doktora Tezi, Adana: Çukurova Üniversitesi Sosyal Bilimler Enstitüsü.

Nakip, M. and V. Özçifci (2015), "Sağlık Hizmetlerinde İlişki Pazarlaması ve Hasta Memnuniyeti: Aksaray Aile Sağlığı Merkezlerinde Uygulama”, Erciyes Üniversitesi İktisadi ve İdari Bilimler Fakültesi Dergisi, Vol. 46, No. 2, 1-20.

Ndubisi, N. O. (2003), "Service Quality: Understanding Customer Perception and Reaction, and its Impact on Business", International Journal of Business, Vol. 5, No. 2, 207-219.

Ndubisi, N. O. (2004), “Understanding the Salience of Cultural Dimensions on Relationship Marketing, it's Underpinnings and Aftermaths", Cross Cultural Management: An International Journal, Vol. 11, No. 3, 70-89.

Ndubisi, N. O. (2009), "Relationship Marketing and Customer Loyalty”, Marketing Intelligence and Planning, Vol. 25, No. 1, 98-106.

Ndubisi, N. O. and K. C. Wah (2005), "Factorial and Discriminant Analyses of the Underpinnings of Relationship Marketing and Customer Satisfaction", International Journal of Bank Marketing, Vol. 23, No. 7, 542-557.

Odabaşı, Y. (2000), Satışta ve Pazarlamada Müşteri İlişkileri Yönetimi, İstanbul: Sistem Yayıncılık.

Oliver, R. L. (1997), Satisfaction: A Behavioral Perspective on the Customer, Boston: Irwin Mcgraw-Hill.

Oliver, R. L. (1999), “Whence consumer loyalty?”, Journal of Marketing, Vol. 63, No. 4, 33-44.

Özgen, P. and G. Şimşek (2015), “ilişskisel Pazarlamanın Müşteri Sadakati Üzerindeki Etkileri Üzerine Ampirik Bir Analiz", Uluslararası Sosyal Araştırmalar Dergisi, Vol. 8, No. 41, 1269-1275.

Palmatier, R. W., L. K. Scheer, K. R. Evans and T. J. Arnold (2008), “Achieving Relationship Marketing Effectiveness in Business-to-Business Exchanges", Journal of the Academy of Marketing Science, Vol. 36, No. 2, 174-190.

Palmatier, R. W., R. P. Dant, D. Grewal and K. R. Evans (2006), “Factors Influencing the Effectiveness of Relationship Marketing: A Meta-analysis”, Journal of Marketing, Vol. 70, No. 4, 136-153.

Panda, T. K. (2013), “Effects of Service Quality and Salesperson Characteristics on Consumer Trust and Relationship Commitment: An Empirical Study on Insurance Buyers in India”, Vision: The Journal of Business Perspective, Vol. 17, No. 4, 285-292.

Pappu, R. and P. Quester (2006), “Does Customer Satisfaction Lead to Improved Brand Equity? An Empirical Examination of Two Categories of Retail Brands", Journal of Product \& Brand Management, Vol. 15, No. 1, 4-14.

Parsa, S. Y. and T. Sadeghi (2015), “Effect of Relationship Marketing on Word of Mouth in Life Insurance with the Approach of Trust and Commitment: Case Study of Karafarin Insurance Agents in Mashhad", International Journal of Management, Accounting and Economics, Vol. 2, No. 10, 12441260.

Putra, W. J. A. and D. P. Putri (2019), “The Mediating Role of Relationship Marketing Between Service Quality and Customer Loyalty", Journal of Relationship Marketing, Vol. 18, No. 3, 233-245.

Richins, M. (1983), “Negative Word-of-Mouth by Dissatisfied Consumers: A Pilot Study”, Journal of Marketing, Vol. 47, No. 1, 68-78.

Rooney, T., E. Krolikowska and H. L. Bruce (2020), “Rethinking Relationship Marketing as Consumer Led and Technology Driven: Propositions for Research and Practice", Journal of Relationship Marketing, Vol. 1, 1-20.

Rusbult, C. E. and B. P. Buunk (1993), "Commitment Processes in Close Relationships: An Interdependence Analysis", Journal of Social and Personal Relationships, Vol. 10, No. 2, 175-204.

Samsa, Ç. (2015), İlişkisel Pazarlama Yöntemlerinin İlişki Kalitesi Üzerindeki Etkileri: Kars GSM Sektörü Örneği, Yayımlanmamış Yüksek Lisans Tezi, Kars: Kafkas Üniversitesi. 
Samsa, Ç. and L. Gelibolu (2015), “İlişkisel Pazarlamanın İlişki Kalitesi Üzerindeki Etkileri: Kars İli Cep Telefonu Kullanıcıları Üzerinde Bir Araştırma", Karabük Üniversitesi Sosyal Bilimler Enstitüsü Dergisi, Vol. 5, No. 2, 285-299.

Schurr, P. H. and J. L. Ozanne, (2019). “Influences on Exchange Processes: Buyers' Preconceptions of a Seller's Trustworthiness and Bargaining Toughness", Journal of Consumer Research, Vol. 11, No. 4, 939-953.

Selnes, F. (1998), "Antecedents and Consequences of Trust and Satisfaction in Buyer-seller Relationships", European Journal of Marketing, Vol. 32, No. 3, 305-322.

Shao, A. T. (2002), Marketing Research: An Aid to Decision Making, Cincinnati: Atomic Dog Publication.

Shetty, A. and S. Basri (2017), "Relationship Orientation in Banking and Insurance Services - A Review of the Evidence", Journal of Indian Business Research, Vol. 10, No. 2, 170-192.

Sin, L. Y., A. C. Tse, O. H. Yau, J. S. Lee and R. Chow (2002), “The Effect of Relationship Marketing Orientation on Business Performance in a Service-Oriented Economy", Journal of Services Marketing, Vol. 16, No. 7, 656-676.

Switala, M. (2013), "Marketing in the Activities of Logistics Service Providers-selected Direct Survey Results", Journal of Economics and Management, Vol. 12, No. 2, 98-110.

Taşkın, E. and S. Bengül (2013), “Sigorta Sektöründe İlişkisel Pazarlama Uygulamalarının Müşteri Bağlllığı Üzerindeki Etkisini Ölçmeye Yönelik Bir Araştırma ve Model Önerisi", Dumlupınar Üniversitesi Sosyal Bilimler Dergisi, EYİ Özel Sayıs1, 503-522.

Tavşancıl, E. (2010), Tutumların Ölçülmesi ve SPSS ile Veri Analizi, Ankara: Nobel.

Tsiotsou, R. (2006), “The Role of Perceived Product Quality and Overall Satisfaction on Purchase Intentions", International Journal of Consumer Studies, Vol. 30, No. 2, 207-217.

Tuzunkan, D. (2017), "Relational Marketing and Customer Relations Management (CRM) Implementations on Automotive Sector the Case of Turkey", International Journal of Applied Engineering Research, Vol. 12, No. 21, 11432-11440.

Üztemur, S. and G. Avcı (2020), "Medya Okuryazarlığı Becerisinin Medya Okuryazarlık Öğretim Özyeterliklerini Yordama Düzeyi", Üçüncü Sektör Sosyal Ekonomi Dergisi, Vol. 55, No. 2, 651-672.

Ventura, K. and A. Küçük (2017), “Endüstriyel Pazarlarda İlişki Kalitesinin Müşteri Sadakatine Etkisi”, Yönetim ve Ekonomi: Celal Bayar Üniversitesi İktisadi ve İdari Bilimler Fakültesi Dergisi, Vol. 24, No. 1, 169-184.

Whyatt, G. and R. Koschek (2003), "Implementing Relationship Marketing: Supermarkets' Perspectives", Marketing Intelligence \& Planning, Vol. 28, No. 3, 582-599.

Winter, S. G. (2003), “Understanding Dynamic Capabilities”, Strategic Management Journal, Vol. 24, No. 10, 991-995.

Yaprak, Ü. (2018), Tüketicilerin Hazır Giyim Firmalarının İlişkisel Pazarlama Faaliyetlerine Yönelik Tutumları: İstanbul İlinde Bir Uygulama, Yayımlanmamış Yüksek Lisans Tezi, Manisa: Manisa Celal Bayar Üniversitesi.

Yazıcıoğlu, Y. and S. Erdoğan (2004), SPSS Uygulamalı Bilimsel Araştırma Yöntemleri, Ankara: Detay Yayıncilik.

Yeğin, T. (2019), İlişkisel Pazarlama Bileşenlerinin Tüketici Temelli Marka Değerine Etkisi: Mobilya Sektöründe Bir Araştırma, Yayımlanmamış Doktora Tezi, Karabük: Karabük Üniversitesi.

Yılmaz, C. (2015), Endüstriyel Pazarlarda İlişki Kalitesinin Öncülleri ve Ardılları, Yayımlanmamış Doktora Tezi, Eskişehir: Anadolu Üniversitesi.

Yi, Y. (1990), A Critical Review of Consumer Satisfaction. V. A. Zeithaml (Eds.), Review of Marketing, Chicago: American Marketing Association.

Yurdakul, M. and Dalkılıç, N. (2006), “ílişkisel Pazarlama Anlayışının Sigorta Müşterilerinin Bağlılığı Üzerindeki Etkisi”, Dumlupınar Üniversitesi Sosyal Bilimler Dergisi, Vol. 16, 255-270. 
Yürük, P. and Ö. Kayapınar (2016), “İlişki Pazarlaması Bileşenleri ile İmaj ve Müşteri Sadakati Arasındaki İlişkilerin İncelenmesine Yönelik bir Uygulama", Balkan ve Yakın Doğu Sosyal Bilimler Dergisi, Vol. 2, 100-110.

Zboja, J. J. and C. M. Voorhees (2006), "The Impact of Brand Trust and Satisfaction on Retailer Repurchase Intentions", Journal of Services Marketing, Vol. 20, No. 6, 381-390. 